\title{
Actions of Crotalus durissus terrificus venom and crotoxin on the isolated rat kidney
}

H.S.A. Monteiro ${ }^{1}$, I.M.S.C. da Silva ${ }^{1}$, A.M.C. Martins ${ }^{2}$ and M.C. Fonteles ${ }^{3}$

\author{
${ }^{1}$ U nidade de Pesquisas Clínicas, Departamento de Fisiologia e Farmacologia, \\ Faculdade de Medicina, Universidade Federal do Ceará, Fortaleza, CE, Brasil \\ ${ }^{2}$ Curso de Farmácia, Centro de Ciências da Saúde, U niversidade de Fortaleza, \\ Fortaleza, CE, Brasil \\ ${ }^{3}$ Faculdade de Veterinária, Universidade Estadual do Ceará, Fortaleza, CE, Brasil
}

Correspondence
H.S.A. Monteiro
Unidade de Pesquisas Clínicas
Departamento de Fisiologia e
Farmacologia, FM, UFC
Caixa Postal 3229
60420-970 Fortaleza, CE
Brasil
Fax: + 55-85-281-5212
E-mail: serrazul@ truenet-ce.com.br
$\ldots \ldots \ldots \ldots . . . \ldots \ldots . . . . . .$.

Received August 1, 2000 Accepted July 13, 2001

\section{Abstract}

Many studies have reported the occurrence of lethal acute renal failure after snakebites. The aim of the present investigation was to determine alterations in renal function produced by Crotalus durissus terrificus venom and crotoxin as well as the histological alterations induced by these venoms. Isolated kidneys from Wistar rats weighing 240 to 280 $\mathrm{g}$ were perfused with Krebs-Henseleit solution containing $6 \mathrm{~g} \%$ of previously dialyzed bovine serum albumin. The effects of Crotalus durissus terrificus venom and crotoxin were studied on glomerular filtration rate (GFR), urinary flow (UF), perfusion pressure (PP) and percentage sodium tubular transport $\left(\% \mathrm{TNa}^{+}\right)$. The infusion of Crotalus durissus terrificus venom $(10 \mu \mathrm{g} / \mathrm{ml})$ and crotoxin $(10 \mu \mathrm{g} / \mathrm{ml})$ increased GFR (control $_{80}=0.78 \pm 0.07$, venom s0 $=1.1 \pm 0.07$, crotoxin $\left._{80}=2.0 \pm 0.05 \mathrm{ml} \mathrm{g}^{-1} \mathrm{~min}^{-1}, \mathrm{P}<0.05\right)$ and UF ( control $_{80}=0.20$ \pm 0.02, venom $_{80}=0.32 \pm 0.03$, crotoxin $_{80}=0.70 \pm 0.05 \mathrm{ml} \mathrm{g}^{-1} \mathrm{~min}^{-1}$, $\mathrm{P}<0.05)$, and decreased $\% \mathrm{TNa}^{+}\left(\right.$control $_{100}=75.0 \pm 2.3$, venom ${ }_{100}=$ $62.9 \pm 1.0$, crotoxin $\left._{80}=69.0 \pm 1.0 \mathrm{ml} \mathrm{g}^{-1} \mathrm{~min}^{-1}, \mathrm{P}<0.05\right)$. The infusion of crude venom tended to reduce PP, although the effect was not significant, whereas with crotoxin PP remained stable during the 100 min of perfusion. The kidneys perfused with crude venom and crotoxin showed abundant protein material in the urinary space and tubules. We conclude that Crotalus durissus terrificus venom and crotoxin, its major component, cause acute nephrotoxicity in the isolated rat kidney. The current experiments demonstrate a direct effect of venom and crotoxin on the perfused isolated kidney.

\section{Introduction}

Snakebites represent a serious public health problem in developing countries due to their high incidence, severity and sequelae (1). In Brazil, fatal cases of bites involving Crotalus durissus terrificus are high, corresponding to $72 \%$ of cases not submitted to

\section{Key words}

- Crotalus durissus

terrificus venom

- Crotoxin

- Kidney specific serum treatment and to $11 \%$ of cases submitted to specific treatment (2). Between 1992 and 1995, 172 annual cases of snakebites were reported by the Health Secretary Office of Ceará State (3).

Crotalus venom produces neurotoxicity, coagulation disorders, systemic myotoxicity and acute renal failure (4), with possible 
additional heart and liver damage (5-7). This venom contains enzymes, toxins (crotoxin, crotamine, gyroxin, convulxin) and several peptides (5). Crotoxin, the major component of Crotalus durissus terrificus venom, is a neurotoxin composed of two subunits, crotapotin and phospholipase $A_{2}$ (8-11). In addition to being neurotoxic, crotoxin also exerts nephrotoxic effects when inoculated into laboratory animals $(2,12)$.

Acute renal failure is a frequent complication observed in victims of snakebites $(2,13)$. The pathogenesis of acute renal failure after viper bites appears to be multifactorial. A direct toxic effect of the venom on tubular cells has been suspected (14). Rhabdomyolysis is also associated with acute renal failure among victims of Crotalus durissus terrificus bites $(15,16)$.

The perfusion method eliminates systemic manifestations that may interfere with renal function, providing an experimental model to assess the direct action of venom on the kidney.

The aim of the present investigation was to examine the nephrotoxicity of Crotalus durissus terrificus venom and crotoxin, its principal component, using the isolated rat kidney model, as well as the histological alterations induced by the venom.

\section{Material and Methods}

All chemical reagents were analytical grade and were purchased from Sigma (St. Louis, MO, USA). Crotalus durissus terrificus venom was obtained from Fundação Ezequiel Dias (Belo Horizonte, MG, Brazil).

\section{Experimental animals}

Adult male Wistar rats weighing 240 to $280 \mathrm{~g}$ were fasted $24 \mathrm{~h}$ before each experiment, with free access to water. The animals were anesthetized with pentobarbital sodium (50 mg/kg body weight).

\section{Perfusion solution}

The perfusion fluid was a modified KrebsHenseleit solution of the following composition: $147 \mathrm{mM} \mathrm{Na}^{+}, 5 \mathrm{mM} \mathrm{K}^{+}, 2.5 \mathrm{mM} \mathrm{Ca}^{2+}$, $2 \mathrm{mM} \mathrm{Mg}^{2+}, 110 \mathrm{mM} \mathrm{Cl}^{-}, 2.5 \mathrm{mM} \mathrm{HCO}_{3}{ }^{-}, 1$ $\mathrm{mM} \mathrm{SO}_{4}{ }^{2-}, 1 \mathrm{mM} \mathrm{PO}_{4}{ }^{2-}$. Bovine serum albu$\min (\mathrm{BSA}, 6 \mathrm{~g} \%$, fraction $\mathrm{V}$ ), $0.075 \mathrm{~g}$ urea, $0.075 \mathrm{~g}$ inulin and $0.15 \mathrm{~g}$ glucose were added to the solution for a final perfusate volume of $100 \mathrm{ml}$. BSA was previously dialyzed for 48 $\mathrm{h}$ at $4^{\circ} \mathrm{C}$ against 1.5 liters Krebs, with changes in the solution after $24 \mathrm{~h}(17,18)$. The $\mathrm{pH}$ was adjusted to 7.4 .

\section{Perfusion system}

The perfusion system was based on Bowman's technique (19) which was modified $(20,21)$ by the addition of an artificial lung to improve oxygenation (22) and a 1.2$\mu \mathrm{m}$ millipore filter (23). The flow calibration and the resistance of the system were determined before each experiment. Perfusion pressure was determined at the tip of a stainless steel cannula and measured with a mercury manometer.

\section{Surgical technique}

The right renal artery was cannulated through the upper mesenteric artery and the kidney was isolated $(24,25)$, allowing uninterrupted perfusion of the kidney.

\section{Experimental protocol}

After an equilibration period of 15 to 20 min, the experiments were carried out for $100 \mathrm{~min}$ with the venom added at $30 \mathrm{~min}$ of perfusion. Perfusion pressure was measured at 5-min intervals. Samples of the perfusate were collected each $10 \mathrm{~min}$ for the determination of sodium, potassium, and inulin levels and osmolality. The urine flow rate was also measured at 10-min intervals. Sodium and potassium concentrations were deter- 
mined by flame photometry (flame photometer Model 445) and inulin levels were also determined $(19,25)$. The osmolality of the samples was measured with an advanced instrument osmometer (WESCOR 5100c vapor pressure) (26).

\section{Histological evaluation}

After the experiment, both right and left kidneys were fixed with $10 \%$ formaldehyde and then cut into small segments which were stained with hematoxylin and eosin and processed for light microscopy observation.

\section{Statistical analysis}

Data were analyzed statistically by analysis of variance (ANOVA). Results are reported as means \pm SEM for eight experiments in each experimental group, with the level of significance set at $\mathrm{P}<0.05$.

\section{Results}

\section{Control group perfused with albumin}

The renal functional parameters of the control group perfused with albumin dissolved in Krebs-Henseleit remained stable throughout the experimental perfusion period. Data are reported as means \pm SEM (Table 1).

\section{Effect of Crotalus durissus terrificus venom and crotoxin}

The crude venom $(10 \mu \mathrm{g} / \mathrm{ml})$ and crotoxin $(10 \mu \mathrm{g} / \mathrm{ml})$ produced in the isolated perfused kidney a significant progressive increase in glomerular filtration rate $\left(\right.$ control $_{80}=0.78 \pm$ $0.07 \mathrm{ml} \mathrm{g}^{-1} \mathrm{~min}^{-1}$, venom $80=1.1 \pm 0.07 \mathrm{ml}$ $\mathrm{g}^{-1} \min ^{-1}, \operatorname{crotoxin}_{80}=2.0 \pm 0.05 \mathrm{ml} \mathrm{g}^{-1}$ $\min ^{-1}, \mathrm{P}<0.05$ ) (Figure 1), and urinary flow (control $_{80}=0.20 \pm 0.02 \mathrm{ml} \mathrm{g}^{-1} \mathrm{~min}^{-1}$, ven$\mathrm{om}_{80}=0.32 \pm 0.03 \mathrm{ml} \mathrm{g}^{-1} \mathrm{~min}^{-1}$, crotoxin $_{80}=$ $0.70 \pm 0.05 \mathrm{ml} \mathrm{g}^{-1} \mathrm{~min}^{-1}, \mathrm{P}<0.05$ ), as illus- trated in Figure 2.

In contrast, in the perfused kidney group, the crude venom and crotoxin significantly decreased percent sodium tubular transport

Table 1. Functional data from control kidneys perfused with Krebs-Henseleit solution containing $6 \mathrm{~g} \%$ bovine serum albumin.

\begin{tabular}{cccccc}
\hline $\begin{array}{c}\text { Time } \\
(\mathrm{min})\end{array}$ & Event & $\begin{array}{c}\text { PP } \\
(\mathrm{mmHg})\end{array}$ & $\begin{array}{c}\text { GFR } \\
\left(\mathrm{ml} \mathrm{g}^{-1} \mathrm{~min}^{-1}\right)\end{array}$ & $\begin{array}{c}\text { UF } \\
\left(\mathrm{ml} \mathrm{g}^{-1} \mathrm{~min}^{-1}\right)\end{array}$ & \% TNa \\
\hline 20 & Control & $120.2 \pm 2.4$ & $0.66 \pm 0.06$ & $0.15 \pm 0.01$ & $75.3 \pm 2.0$ \\
40 & Control & $120.8 \pm 3.3$ & $0.68 \pm 0.06$ & $0.17 \pm 0.01$ & $76.5 \pm 2.6$ \\
60 & Control & $122.5 \pm 3.9$ & $0.75 \pm 0.03$ & $0.20 \pm 0.02$ & $77.9 \pm 1.9$ \\
80 & Control & $122.0 \pm 3.5$ & $0.78 \pm 0.07$ & $0.20 \pm 0.02$ & $78.5 \pm 2.0$ \\
100 & Control & $125.0 \pm 4.0$ & $0.79 \pm 0.07$ & $0.20 \pm 0.02$ & $75.0 \pm 2.3$ \\
\hline
\end{tabular}

Results are reported as means \pm SEM of control kidneys $(N=6)$. PP $=$ perfusion pressure, GFR = glomerular filtration rate, UF = urinary flow, $\% \mathrm{TNa}^{+}=$percent sodium tubular transport.

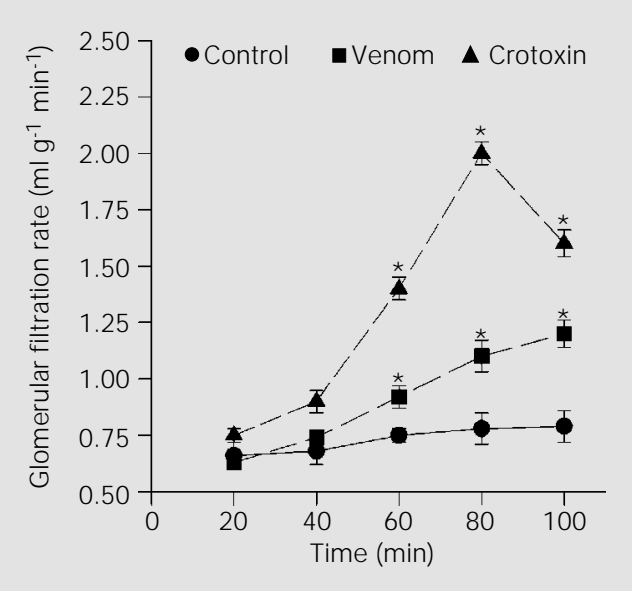

Figure 1. Glomerular filtration rate of kidneys perfused with Crotalus durissus terrificus venom $(10 \mu \mathrm{g} / \mathrm{ml})$ and crotoxin (10 $\mu \mathrm{g} / \mathrm{ml})$ versus control kidneys. Values are reported as means \pm SEM $(\mathrm{N}=8)$. $* \mathrm{P}<0.05$ compared to control (ANOVA).

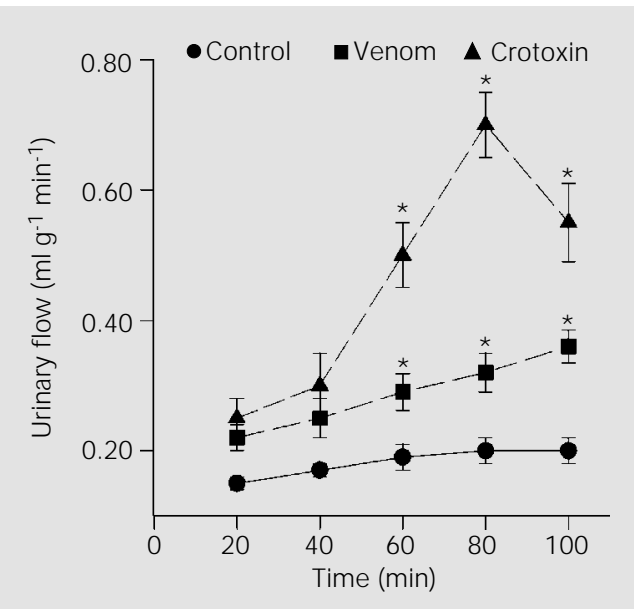

Figure 2. Urinary flow of kidneys perfused with Crotalus durissus terrificus venom $(10 \mu \mathrm{g} / \mathrm{ml})$ and crotoxin $(10 \mu \mathrm{g} / \mathrm{ml})$ versus control kidneys. Values are reported as means \pm SEM $(\mathrm{N}=8)$. $* \mathrm{P}<0.05$ compared to control (ANOVA). 
(control $_{100}=75.0 \pm 2.3 \mathrm{ml} \mathrm{g}-1 \mathrm{~min}^{-1}$, venom $_{100}=62.9 \pm 1.0 \mathrm{ml} \mathrm{g}^{-1} \mathrm{~min}^{-1}, \operatorname{crotoxin}_{80}=$ $69.0 \pm 1.0 \mathrm{ml} \mathrm{g}^{-1} \mathrm{~min}^{-1}, \mathrm{P}<0.05$ ) (Figure 3). In the kidneys perfused with $10 \mu \mathrm{g} / \mathrm{ml}$ crotoxin there was no significant decrease in perfusion pressure, with mixed responses in individual experiments. This trend was also observed for the group treated with the crude venom (Figure 4).

\section{Histological evaluation of control group kidneys and kidneys treated with Crotalus durissus terrificus venom and crotoxin}

The histological evaluation of kidneys from the control group revealed good preservation in contrast to kidneys treated with

Figure 3. Percent sodium tubular transport $\left(\% \mathrm{TNa}^{+}\right)$of kidneys perfused with Crotalus durissus terrificus venom $(10 \mu \mathrm{g} / \mathrm{ml})$ and crotoxin $(10 \mu \mathrm{g} / \mathrm{ml})$ versus control kidneys. Values are reported as means \pm SEM $(\mathrm{N}=8)$. $* \mathrm{P}<0.05$ compared to control (ANOVA).

Figure 4. Perfusion pressure of kidneys treated with Crotalus durissus terrificus venom $(10 \mu \mathrm{g} /$ $\mathrm{ml})$ and crotoxin $(10 \mu \mathrm{g} / \mathrm{ml})$ versus control kidneys. Values are reported as means $\pm \mathrm{SEM}$ ( $\mathrm{N}=$ 8). The effects were not significant (ANOVA).
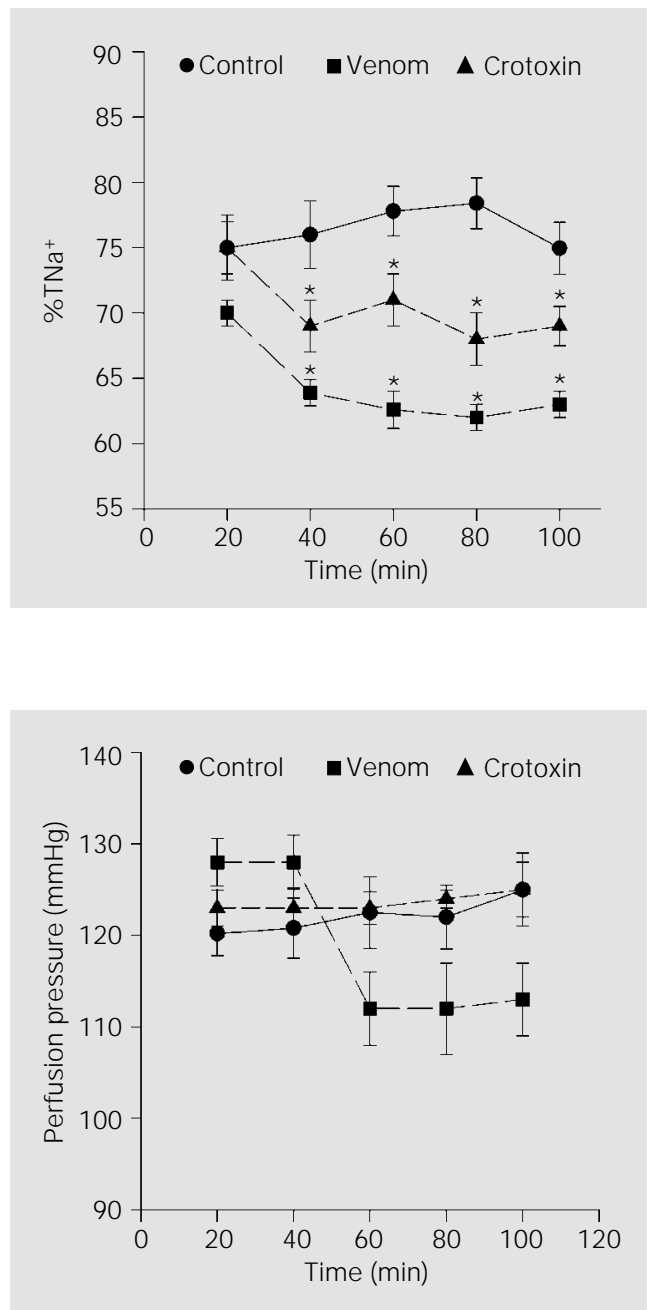

crude venom and crotoxin which showed abundant protein material in the urinary space and tubules.

\section{Discussion}

Most venoms probably exert their effects on almost all cells or tissues and their pharmacological properties are determined by various biologically active components (12). Nephrotoxicity is a complication observed in most snakebites (4). Snake venom produces effects that may be directly or indirectly promoted by the release of active pharmacological substances (5).

The presence of many natriuretic peptides has been reported in snake venom $(27,28)$. A gene has been identified that codes for seven bradykinin-potentiating peptides and also a $\mathrm{C}$ type natriuretic peptide in the venom of Bothrops jararaca by Camargo's group (29) and the diuretic and natriuretic effects promoted by the peptide called DNP, isolated from the serpent Dendroaspis angusticeps (green mamba), have been recently described (30). Evaluation of renal functional parameters after crude venom and crotoxin administration has suggested a direct effect on the glomeruli resulting in an increase in glomerular filtration rate and a rise in urinary flow rate that could be explained by the presence of natriuretic peptides in the venom. We believe that this discrepancy regarding polyuria instead of the oliguria found in clinical envenomation is due to lack of myoglobinuria in the isolated rat kidney model. Sodium excretion depends on the relationship between glomerular filtration rate and sodium reabsorption. In the present experiments, the fractional sodium tubular transport was reduced in the venom-treated group, and crotoxin was also able to produce this effect when compared to the controls.

We recently demonstrated that Crotalus durissus cascavella venom increased the perfusion pressure in the isolated rat kidney 
(26). In the kidney perfused with Crotalus durissus terrificus crude venom, the perfusion pressure tended to decrease, but not significantly, so crotoxin had no prominent effect on the kidney vasculature.

A large amount of protein material was observed in the glomeruli of the crude venom and in the crotoxin-treated group, probably because of a direct toxic effect of the venom on the glomeruli and tubules or due to an increase in vascular permeability as a result of endothelial injury which could not be demonstrated by light microscopy.

The enzymatic action of phospholipase on the membrane phospholipid can change membrane permeability by itself(31). A factor has been described in $B$. jararaca venom which contains phospholipases and which may be related to prostaglandin and leukotriene formation, thus causing an increase in vascular permeability, edema and low blood pressure (32). This could account for protein leakage into the tubular spaces.

The release of mediators, including biological amines such as histamine, serotonin or prostaglandins, may play a major role in the pathogenesis of edema. The release of these compounds is related to an increase in capillary permeability, a drop in blood pressure and shock. The enzymes involved in these processes are the kininogenases, phospholipases and hydrolases of arginine ester. The release of histamine is related to phospholipase concentrations (33).

We also demonstrated recently in the isolated rat kidney that the venom of Crotalus durissus cascavella caused lesions by a direct action on the tubular and glomerular cells or indirectly by the release of mediators from the endothelial layer (26).

We conclude that Crotalus durissus terrificus venom and crotoxin, its major component, caused acute nephrotoxicity in the isolated rat kidney, which differed from the one described for rattlesnakes. We suggest that the renal alterations due to Crotalus durissus terrificus venom may also be the result of a direct action or release of mediators by kidney tissues. The current experiments are the first demonstration of a direct effect of the venom and crotoxin on the isolated kidney in the absence of systemic factors and in a cell-free perfusate.

\section{References}

1. Ribeiro LA, Albuquerque MJ , De Campos VA, Katz G, Takaoka NY, Lebrao ML \& J orge MT (1998). Deaths caused by venomous snakes in the State of São Paulo: evaluation of 43 cases from 1988 to 1993. Revista da Associação Médica Brasileira, 44: 312-318.

2. Amaral CFS, Resende NA, Da Silva OA, Ribeiro MMF, Magalhães RA, Reis RJ, Cameiro J G \& Castro J RS (1986). Insuficiência renal aguda secundária a acidentes ofídicos botrópico e crotálico. Análise de 63 casos. Revista do Instituto de Medicina Tropical de São Paulo, 28: 220-227.

3. Feitosa RFG, Melo IMLA \& M onteiro HSA (1997). Epidemiologia dos acidentes por serpentes peçonhentas no estado do Ceará-Brasil. Revista da Sociedade Brasileira de Medicina Tropical, 30: 295-301.

4. Sitprija V \& Chaiyabutr N (1999). Nephrotoxicity in snake envenomation. J ournal of Natural Toxins, 8: 271-277.

5. Barraviera B, Lamonte B, Tarkowski A, Hanson LA \& M eira D (1995). Acute phase reactions including cytokins in patients bitten by Bothrops spp. and Crotalus durissus terrificus in Brazil. J oumal of Venomous Animals and Toxins, 1: 11-22.

6. Cupo P, Azevedo-Marques MM \& Hering SE (1990). Acute myocardial infarction-like enzyme profile in human victims of Crotalus durissus terrificus envenoming. Transactions of the Royal Society of Tropical Medicine and Hygiene, 84: 447-451.

7. Siqueira J E, Higuchi $M L$, Nabut $N$, Lose A, SouzaJ K \& Nakashima M (1990). Lesão miocárdica em acidentes ofídicos pela espécie Crotalus durissus terrificus (cascavel). Relato de caso. Arquivos Brasileiros de Cardiologia, 54: 323-325.

8. Bon C, Bouchier C, Choumet V, Faure G, J iang $M$, Lambezat $M$, Radvanyi $F$ \&
Saliou B (1989). Crotoxin, half-century of investigation on a phospholipase $A_{2}$ neurotoxin. Acta Physiologica et Pharmacologica Latinoamericana, 39: 439-448.

9. Faure G, Choumet V, Bouchier C, Camoin L, Guillaume J , Monegier B, Vuilhorgne M $\&$ Bon C (1994). The origin of the diversity of crotoxin isoforms in the venom of Crotalus durissus terrificus. European J ournal of Biochemistry, 223: 161-164.

10. Araújo DM \& Beirão PSC (1993). Effect of crotoxin on the action potential kinetics of frog skeletal muscle. Brazilian J ournal of Medical and Biological Research, 26: 1111-1121.

11. Moreira EG, Nascimento N, Rosa GJ M, Rogeo J R \& Vassilieff VS (1996). Crotoxininduced behavioral effects in rats. Brazilian J ournal of Medical and Biological Research, 29: 629-632.

12. Sanchez EF, Freitas TV, Ferreira-Alves DL, 
Velarde DT, Diniz MR, Cordeiro MN, Agostini-Cotta G \& Diniz CR (1992). Biological activities of venoms from South American snakes. Toxicon, 30: 95-103.

13. Burdmann EA, Woronik V, Prado EBA, Abdulkader RC, Saldanha LB, Barreto OCO \& Marcondes M (1993). Snakebite induced acute renal failure: an experimental model. American J ournal of Tropical Medicine and Hygiene, 48: 82-88.

14. Nancy G, Ahlstrom MD, Luginbuhl MDW \& Tisher MDC (1991). Acute anuric renal failure after pygmy rattlesnake bite. Southern Medical J ournal, 84: 783-785.

15. Azevedo-Marques MM, Cupo P, Coimbra TM, Hering SE, Rossi MA \& Laure CJ (1985). Myonecrosis, myoglobinuria and acute renal failure induced by SouthAmerican rattlesnake (Crotalus durissus terrificus) envenomation in Brazil. Toxicon, 23: 631-636.

16. Azevedo-Marques MM, Hering SE \& Cupo P (1987). Evidence that Crotalus durissus terrificus (South American rattlesnake) envenomation in humans causes myolysis rather than hemolysis. Toxicon, 25: 1163-1168.

17. Hanson RW \& Ballard FS (1968). Citrate, pyruvate and lactate contaminants of commercial serum albumin. J ournal of Lipid Research, 9: 667-668.

18. Gregg GM, Cohen J J , Black AY, Espeland MA \& Feldstein MC (1978). Effects of glucose and insulin on metabolism and function of perfused rat kidney. American J ournal of Physiology, 235: F52-F61.

19. Bowman RH (1970). Gluconeogenesis in the isolated perfused rat kidney. J ournal of Biological Chemistry, 245: 1604-1612.

20. Hamilton RL, Benny NM, Williams MC \& Severin-Ghaus EMA (1974). Simple and inexpensive membrane "lung" for small organ perfusion. J ournal of Lipid Research, 15: 182-186.

21. Fonteles MC, Greenberg RN, Monteiro HSA, Currie MG \& Forte LR (1998). Natriuretic and kaliuretic activities of guanylin and uroguanylin in the isolated perfused rat kidney. American J ournal of Physiology, 275: F191-F197.

22. Pegg DE (1971). Vascular resistance of the isolated rabbit kidney. Cryobiology, 8: 431-440.

23. Bahlmann J, Giebisch G, Ochwadt B \& Schoeppe W (1967). Micropuncture study of isolated perfused rat kidney. American J ournal of Physiology, 212: 77-82.

24. Nishiitsutji-Uwo GM, Ross BD \& Krebs HA (1967). Metabolic activities of the isolated perfused rat kidney. Biochemical J ournal, 103: 852-862.

25. Walson M, Davidson DG \& Orloff J (1955). The renal clearance of alkali-stable inulin. J ournal of Clinical Investigation, 34: 15201523.

26. Martins $A M C$, Monteiro HSA, Guedes J unior EO, Menezes DB \& Fonteles MC (1998). Effects of Crotalus durissus cascavella venom in the isolated rat kidney. Toxicon, 36: 1441-1450.

27. Higuchi $S$, Murayama N, Saguchi K, Ohi H, Fujita Y, Camargo AC, Ogawa T, Deshimaru M \& Ohno M (1999). Bradykinin-potentiating peptides and C-type natriuretic peptides from snake venom. Immunopharmacology, 44: 129-135.
28. Schweitz $H$, Vigne $P$, Moinier $D$, Frelin $C$ $\&$ Lazdunski M (1992). A new member of the natriuretic peptide family is present in the venom of the green mamba (Dendroaspis angusticeps). J ournal of Biological Chemistry, 267: 13928-13932.

29. Murayama N, Hayashi MA, Ohi H, Ferreira LA, Hermann W, Saito H, Fujita Y, Higuchi $\mathrm{S}$, Fernandes $\mathrm{BL}$, Yamane $\mathrm{T} \&$ de $\mathrm{Ca}$ margo AC (1997). Cloning and sequence analysis of a Bothrops jararaca cDNA encoding a precursor of seven bradykininpotentiating peptides and C-type natriuretic peptide. Proceedings of the National Academy of Sciences, USA, 94: 11891193.

30. Lisy $O$, J ougasaki $M$, Heublein DM, Schirger J A, Chen $\mathrm{HH}$, Wennberg PW \& Burnett J C (1999). Renal actions of synthetic Dendroaspis natriuretic peptide. Kidney International, 56: 502-508.

31. Lima EG, Costa PI \& Laure JC (1989). South American rattlesnake venom: its hemolytic power. Revista da Sociedade Brasileira de Medicina Tropical, 22: 171175.

32. Vargaftig BB, Bhargava N \& Bonta IL (1974). Haemorrhagic and permeability increasing effects of Bothrops jararaca and other Crotalidae venoms as related to amine or kinin release. Agents and Actions, 4: 163-168.

33. Hylop S \& De Nucci G (1993). Prostaglandin biosynthesis in the microcirculation: Regulation by endothelial and non-endothelial factors. Prostaglandins, Leukotrienes and Essential Fatty Acids, 49: 723760. 